\title{
Progress and Challenges in Global Disaster Reduction
}

\author{
Summary of an Address Given at Beijing Normal University, 10 January 2013, Beijing, China \\ Margareta Wahlström \\ United Nations Special Representative of the Secretary-General (SRSG) for Disaster Risk Reduction, UNISDR
}

For 30 to 40 years, scientists have been trying to demonstrate to decision makers in government and to everyday people that there are many actions they can take to reduce the impact of disasters. But in many parts of the world there is still a culture of fear around disasters.

Nature is not responsible for disasters-people are. Part of the reason for why disasters occur lies in the way human beings build societies and expand settlements. A thousand years ago, people living in rural communities relied on river flooding to fertilize their land. But today when flooding happens it very quickly becomes a disaster because on those traditional agricultural lands we have built new cities and ports, which in some ways are necessary for progress but also pose risks.

We are living in a consumer-driven period of human history where the available resources on the planet are out of balance with our aspirations for perpetual economic growth. We have an opportunity to shift that balance by recognizing that the planet's resources are not endless. But that requires a big mind-shift.

We should all aspire to live well. But what can we do to also take a bit more responsibility? Take, for example, the enormous amounts of garbage we are creating from the packaging for our cell phones, our TVs, and other consumer goods. Where does it go? These are the things we need to be conscious of and take individual responsibility for.

Similarly, the purpose of disaster risk reduction is to create a very different attitude to disasters and to risk. It is an attempt to empower people and get each individual to ask, "What can I do to protect myself and to minimize risk?" It is about cultivating an attitude of not accepting the inevitability of disasters. But it requires a big leap in the way we act. The work that you are doing, the studies and research that you are embarking on, is critical for helping to make that shift happen not just in theory but also in practice.

At the end of the period of the Yokohama Strategy and Plan of Action for a Safer World in the mid-1990s, the scientific community was struggling to make themselves heard on the issue of disaster risk reduction. People working in this field realized that it was clearly not enough to produce scientific knowledge. It was also necessary to try to change behavior through advocacy, communication, and education. The United Nations created the International Strategy for Disaster Reduction (ISDR), which was formally established by the United Nations General Assembly in 1999. Next, the disaster risk reduction community began working towards a common framework for international action to give guidance to nations and communities on how to reduce disaster risk through a structure that empowers people. A conference on disaster reduction was planned for January 2005 in Kobe, Japan.

Then, on 26 December 2004, the Indian Ocean Tsunami happened and changed the way we looked at disasters. There was an enormous loss of life. People in southeast Asia, Sri Lanka, Somalia, and also in Germany, Sweden, Finland, and Norway - countries where hundreds of thousands of tourists and visitors came from who were also affected by the tsunami -were deeply affected. In some places, people turned against their governments. They felt that their governments were totally unprepared to handle such a crisis that affected so many people.

Because this catastrophe happened just weeks before the Kobe event, it completely changed the nature of the conference. The Kobe conference resulted in very strong support for the Hyogo Framework for Action. This framework is aimed at helping nations and communities to save lives, economic assets, and environmental assets. Countries agreed on three strategic goals: the full integration of disaster risk reduction into sustainable development policies and planning; the strengthening of institutions and capacities to build resilience; and the systematic incorporation of risk reduction approaches into the implementation of emergency preparedness, response, and recovery programs.

The three strategic goals are further divided into the Hyogo Framework's five priorities for action: first, to ensure that risk reduction is a national and local priority supported by a strong institutional base, laws and policies, and a budget; second, to identify assets and monitor disaster risks, and strengthen early warning systems; and third, to turn knowledge into practical action.

The fourth priority is the most challenging and forms the core of the framework: how to reduce underlying risk factors. 
This refers to climate change, technological risk, water shortages, and other big developmental challenges. It is the aspiration of all people who work in disaster risk reduction to see risk reduction mainstreamed into development planning. The realization of the dream is coming closer but we are still far from being able to say that we have succeeded. We have not yet been able to shift people's mindsets, including the mindset of political leaders.

The fifth priority is to strengthen countries' preparedness. Countries asked ISDR to set up a voluntary reporting system. At a time when the world is trying to develop a new global vision for a sustainable future, having a voluntary cooperation framework is something really very powerful. One impressive achievement that countries reported was the creation of legislation on disaster risk reduction after 2005. Nations also reported greater success with early warning systems. The Indian Ocean tsunami generated enormous work on early warning systems so that they are much stronger today. Not long ago, there was a tsunami warning after an earthquake struck just outside Sumatra. The tsunami warning went out and immediately triggered action. In Sri Lanka, people were off the beaches and out of the villages in no time. So the awareness of the dangers of tsunamis is very high now.

One lingering challenge we face is how to align the theoretical and empirical work of scientists more closely with the practical work of countries and institutions. How can we have enough information in the public domain so that individuals can find information about risk if they want to? In a crisis, people want to have authoritative information. In Europe, two years ago when the Icelandic volcano stopped almost all air traffic for three days, the biggest problem was that people completely distrusted government information. A subsequent survey in the European Union revealed that people trusted scientists but not government.

The urgency to act comes from the fact that disaster risk is increasing faster than at any previous time in history. Because we have more people living on the planet, our cities are growing faster than ever before, and our wealth is larger than before. The richest countries have the highest losses proportionally. But poor countries are also hurt. In small island states and poor countries that are affected by cyclones every year, one single cyclone can reduce the GDP of an economy that is based on limited sources of income, such as agriculture or tourism, by 10-12 percent.

The significance of this in today's climate of rapid privatization is that we have to involve business. In most countries, it is through both public and private investment that infrastructure is built. If the business and private sector do not agree that it is in their interest to reduce the losses of disasters, then we will not be able to reduce risk.

Population growth in the world's urban areas is increasing much faster than in other areas. Africa has some of the fastest growing urban communities in the world, after Asia. In Latin America, already more than 70 percent of all people live in urban areas. Cities will continue to grow but they are also very exposed because cities grow fastest around coastal areas and where there is water for transport. Economic assets of countries are accumulating in coastal belts and river deltas. At the same time, these areas are the most highly prone to disasters.

The path of the future is quite clear. We work a lot with local government officials and in a recent meeting with mayors I said it was my impression that many cities are much richer - and therefore more able to act - than central governments. I was first greeted with silence, and then some mayors said, "Actually, yes. You are right." So, hopefully, we will see a shift among local governments, with more readiness to allow local governments to assume increasing responsibility for disaster risk reduction.

As for new and emerging risks, looking 20 or 40 years ahead, our lifestyle is going to interact with nature and create situations and consequences we have not started to imagine. This relates not only to nuclear power plants, but also chemical industries, environmental damage, and landfills full of garbage. Add to that demographic changes - not only aging populations but longer life spans. How are we going to adjust our ability to deal with emotional and intellectual development if we are going to live until the age of 125 ?

Climate change is having a big impact on cities. Just look at the images from Australia in the media, where people are hiding in the rivers from terrible forest fires. Forest fires, economically speaking, may not be as serious as flooding, but they are occurring more frequently in the United States, southern Europe, Russia and probably China as well. They have many health impacts on people and will certainly change the way we live.

There are very interesting surveys in some countries about how people insure themselves and their property. A particularly interesting survey conducted on the east coast of the United States where hurricanes are a common occurrence showed that people did not ensure their houses but they did insure their cars. There is something about people's choiceswhat is most important to them when they have a limited amount of money - that is not as rational as we think it should be. It is difficult to account for this gap between what we know and how we act in given circumstances. I encourage you to take interest in that in your research.

Government officials that talk to us say that their institutional structures are not appropriate for disaster risk reduction because risk management in the framework of government is very low down in the hierarchy with little money and no authority to coordinate what other government departments do. Governments also claim they suffer from an inability to use all the available information. It is not that information is not accessible, the problem is how to process it. Governments want to be able to set targets and measure progress, but find there is not enough disaster risk reduction expertise. For example, governments in Africa often make requests for 
capacity strengthening. When it comes to finding solutions to droughts and water shortages, governments assert that they would like to have even more planners and people around who understand the way institutions, people, and the economy interface with disasters.

Work that began under the Hyogo Framework for Action should not end in 2015. We have started consultations with countries, organizations, academia, NGOs, and civil society to ask the question: When we get to 2015, what are the most important issues that the next 10-year work period should focus on? What areas should be given the highest priority?

There has always been a strong drive to integrate the understanding of disasters into education. It is happening well at the primary level in schools, and somewhat well at the secondary level, but is largely absent at the tertiary level. There are some networks of academic institutions, mainly in Asia and Latin America, that are working hard to get risk education into very crowded curriculums. While it may be difficult, it is nevertheless important to train engineers and people from other disciplines to understand risk so that they can mitigate for it.

Everywhere in the world people are calling for more political support and leadership. There is a sense of urgency that is beginning to grow in the OECD countries, the richest countries in the world - they are beginning to work together on a disaster risk assessment and risk financing framework. China has been part of this collaboration. Now we must ensure that leaders from the G20 are working on these issues as well, alongside leaders of APEC, ASEAN, and other regional organizations.

In early 2015, we will meet in Japan at the World Conference on Disaster Risk Reduction to agree on the next iteration of the Hyogo Framework for Action. An important contribution to that will be the one scientists will make. Scientists need to answer two questions: what will disaster risk look like in 40 years time? And what can scientists do to help societies continue to mitigate and reduce the impacts of disasters? These are the questions that I turn over to you.

Open Access This article is distributed under the terms of the Creative Commons Attribution License which permits any use, distribution, and reproduction in any medium, provided the original author(s) and source are credited. 